\title{
ФЕНОМЕН ПОТВОРНОГО У КОНЦЕПТУАЛЬНОМУ ПРОСТОРІ ЄВРОПЕЙСЬКОЇ ГУМАНІСТИКИ: «РЕАБІЛІТАЦІЯ» КАРЛА РОЗЕНКРАНЦА
}

У статті розглядається праия німецького філософа К. Розенкранца «Естетика потворного» (1853) - багатоаспектне теоретичне дослідження, кониептуальне наповнення якого виявило різні аспекти цього складного феномена, що, відкриваючи вихід у контекст суміжних теоретичних проблем, актуалізує обтрунтування означеної пращі як своєрідного фундаменту аналізу потворного в умовах $X X \mathrm{~cm}$.

Ключові слова: потворне, прекрасне, комічне, сміх, міждисциплінарний підхід, порівняльний аналіз, «теоретична реабілітація».

В статье рассматривается работа немеикого философа К. Розенкраниа «Эстетика безобразного» (1853), многоаспектное теоретическое исследование, кониептуальное наполнение которого открыло разные аспекты этого сложного феномена, что, в свою очередь, обусловило выход в контекст смежных теоретических проблем, актуализировав обоснование данной работы как своеобразного фундамента анализа безобразного в условиях $X X \mathrm{~cm}$.

Ключевые слова: безобразное, прекрасное, комичное, смех, междисииплинарный подход, сравнительный анализ, «теоретическая реабилитация».

The article describes the work of the German philosopher K. Rosenkranz «aesthetics of ugly» (1853), a multidimensional theoretical study, conceptual filling which opened the different aspects of this complex phenomenon, which, in turn, led output in the context of the related theoretical problems by updating the rationale of this work as a kind of Foundation of the analysis of the ugly in the face of the twentieth century.

Key words: ugly, beautiful, comical, laughter, interdisciplinary, comparative, "theoretical rehabilitation».

В історії естетики проблема категоріального апарату, як відомо, була теоретичним пріоритетом і в добу античності, і залишається ним в умовах сьогодення, даючи змогу простежити динаміку руху естетичної думки та ті показові зміни, що їх він неминуче спричинив. Здійснюючи періодизацію естетичного поступу, яка відверто активізувалася на межі XX-XXI ст., науковці, природно, враховували чимало чинників, що визначили специфіку їі теоретичного поля. Серед них, вочевидь, важливе місце посіло категоріальне питання, дослідження якого, значною мірою, зумовило безпосередній вихід і у площину понятійного апарату, i у концептуальний контекст естетичної науки.

Не вдаючись до реконструкції загальновідомих положень, нагадаємо, проте, що традиційно завершення іії класичної доби ототожнюють 3 доробком Г.В.Ф. Гегеля, початок нової - некласичної, - передусім, пов'язують з іменами А. Шопенгауера, С. К’єркегора, Ф. Ніцше, 3. Фрей- да, А. Бергсона. Наразі, звернімо увагу на один, доволі показовий факт, а саме: на відміну від представників класичної, репрезентанти некласичної естетики виявляли меншу зацікавленість категоріальним апаратом. Якщо ж це відбувалося, розгортали свої розвідки у, так би мовити, «опосередкованому форматі», що, проте, дає можливість визначити принаймні одну естетичну категорію, яка імпліцитно була наявною у працях більшості 3 них — категорію потворного.

Як відомо, звернення до цієї проблеми, так чи інакше, відбувалося на різних етапах в історії естетичної думки. Одним з хрестоматійних прикладів у даному зв'язку є відоме твердження Аристотеля, що його вельми активно цитують дослідники: «На те, на що дивитися неприємно, зображення того ми розглядаємо із задоволенням» $[8,50]$. Певні звернення до феномена потворного можемо спостерігати і в інші періоди класичної естетичної доби, проте безсумнівний теоретичний прорив у 
цьому плані було здійснено у відомій праці К. Розенкранца (1805-1878) — «Естетика потворного».

Наразі завважимо, що означене дослідження, фактично ніколи не було серед теоретичних пріоритетів української гуманістики, зокрема, через відсутність його повноцінного перекладу. Проте сьогодні відкриваються всі можливості кооптувати «Естетику потворного» у вітчизняний гуманітарний контекст, а саме - площину власне естетики, культурології та мистецтвознавства завдяки перекладу їі доктором філософських наук, професором М. О. Шкепу, котра до того ж здійснила низку оригінальних авторських напрацювань у цій царині.

Перш ніж виокремити і прокоментувати наріжні положення дослідження К. Розенкранца, акцентуємо увагу, що свою працю німецький учений написав у середині XIX ст., а саме - у 1853 р. Наголосити на цьому нас спонукають, по-перше загальнонаукові критерії оформлення теоретичної статті, а по-друге - вже згадуване питання логіки періодизації естетичної науки. Адже «Естетику потворного» було оприлюднено у, так би мовити, перехідний період, коли класична доба в історії естетичної думки вже відходила, а некласична ще не розпочалася.

Наразі виокремимо ще одну вельми показову обставину - офіційну причетність К. Розенкранца до кола Г.В.Ф. Гегеля, «концептуальні стосунки» між якими виявилися доволі суперечливими i, зрештою, спричинили відомий висновок класика німецької філософії: «Ніхто з моїх учнів, — відзначав Гегель, - не зрозумів мосї системи. Зрозумів тільки Розенкранц і то неправильно».

Слушність цього оригінального твердження, показовим чином, підтверджує специфіка підходів учених, а саме - розуміння Г.В.Ф. Гегелем естетики виключно як науки про прекрасне, і відверту артикуляцію К. Розенкранца на естетиці потворного. Такі діаметрально протилежні позиції філософів, що чітко визначили специфіку їхніх «категоріальних пріоритетів», знову актуалізують питання періодизації естетичної науки. I, якщо приналежність ідей Гегеля до класичної естетичної проблематики не викликає жодних сумнівів, відповідні концептуальні орієнтири Розенкранца, вочевидь, стимулюють 3 цього приводу чимало питань.

Наразі наголосимо, що передмову до «Естетики потворного» він завершує показовою цитатою Г. Е. Лессінга, відповідні ідеї якого доволі часто фігурують у праці К. Розенкранца : «Я не писав для дітей, котрі з гідністю крокують до школи, тримаючи у руках Овідія, який не був зрозумілий їхніми вчителями» $[5,36]$. Цим спостереженням свого великого співвітчизника К. Розенкранц, зрозуміло, скористався не задля акцентуації приналежності «Естетики потворного» до категорії «дорослої літератури». Імовірно, у твердженні Лессінга його увагу привертав очевидний акцент на природному «конфлікті інтересів» між учнями і вчителями, що, тим більш, стає неминучим, коли йдеться про відомого вчителя і не менш відомого учня. Проте наразі, на нашу думку, ситуація виявляється більш неоднозначною, ніж фактична суперечка на рівні Г.В.Ф. Гегель - К. Розенкранц.

Навіть загальний огляд «Естетики потворного» та похідні проблеми, що їх актуалізує це дослідження, провокують зіставити його з певними положеннями метрів некласичної естетики, передусім, - А. Шопенгауера, Ф. Ніцше, С. К'єркегора та 3. Фрейда, що, вочевидь, виявить «теоретичну суголосність» між ними. Відтак «наукові інтереси» К. Розенкранца свідчать про його доволі відверте тяжіння до проблематики некласичної естетики, стимулюючи, таким чином, розмисли щодо його «концептуального посередництва» між класичним і некласичним періодами в історії естетики. Однак цей ракурс ми залишаємо за собою на перспективу, наразі ж зосередимося на засадних чинниках «Естетики потворного» задля загальної характеристики їі сутнісних ознак, що, на нашу думку, заклали фундамент цілісного аналізу цієї категорії та супутніх їй проблем.

Наразі увагу привертає твердження ученого, яке, фактично, стає «теоретичним лейтмотивом» цієї праці і стосується питання «понятійної залежності» потворного, що «його можна збагнути лише як умовне, у співвідношенні з іншими поняттями» $[5,39]$. Безперечний пріоритет у цьому зіставленні посідає дихотомія прекрасне-потворне, яка, у тому чи іншому контексті, постійно фігурує у розвідці К. Розенкранца: «... потворне існує лише такою мірою, що в ній існує прекрасне як його позитивна передумова. Якби не існувало прекрасне, не існувало б і потворне, оскільки воно всього лише негативність прекрасного» $[5,39]$.

Свої аргументи щодо взаємозалежності прекрасного і потворного К. Розенкранц фактично вибудовує, спираючись на принцип гегелівської діалектики: «Прекрасне ставиться до потворного виключно негативно, оскільки воно $є$ прекрасним настільки, наскільки не потворним, а потворне $\epsilon$ потворним лише тією мірою, якою воно не прекрасне» $[5,39]$. Однак «дух Гегеля», так би мовити, вирує і в інших контекстах «Естетики потворного», зокрема — на рівні твердження К. Розенкранца щодо відносності прекрасного: 
«Наше дослідження первісно передбачає адекватне розуміння відносної природи прекрасного, яка укорінена у самому мистецтві і може бути виражена наступним чином: від того, що якась річ прекрасніша за іншу, не можна зробити висновок, що менш красива річ $є$ потворною» $[5,42]$.

Наразі наголосимо, що таке спостереження дає змогу К. Розенкранцу екстраполювати «принцип відносності», котрий $\epsilon$, як вже акцентувалося, одним із наріжних у його праці, у площину проблеми видової специфіки мистецтва. Надалі філософ розглядатиме феномен потворного безпосередньо у мистецькому контексті, зосереджуючись на конкретних художніх творах, проте у цьому зв'язку увагу привертає його акцент, що фактично стосується питання супідрядності видів мистецтва. Так, К. Розенкранц відзначає: «Архітектура, скульптура, живопис, музика чи поезія абсолютно рівні між собою як види мистецтва, але правильно i те, що в їх вище переліченій послідовності виражена ієрархія, в якій безпосередньо досліджуваний вид домінує над попереднім у можливостях більш адекватного вираження сутності і свободи духу» $[5,42]$. При цьому, розвиваючи свою думку щодо ідеї відносності, учений зазначатиме, що «таким чином, $<\ldots>$ архітектура менш досконала, ніж скульптура, живопис та ін.». I хоча на наступному етапі свого концептуального ланцюга К. Розенкранц, безпосередньо, вийде у площину феномена потворного - «супідрядність < ..> жодним чином не відноситься до потворного» $[5,43]$, увагу привертає чітка ієрархія видів мистецтва, визначена науковцем.

Вочевидь, підхід, який демонструє К. Розенкранц, свідчить, що він дуже добре засвоїв «науку логіки» Г.В.Ф. Гегеля стосовно його «абсолютної ідеї», яку, на теренах мистецтва, визначив рух від архітектури - через скульптуру, живопис, музику — до найвищого рівня у гегелівській мистецькій ієрархії - поезії, що, у свою чергу, відкривав вихід у сферу релігії. Таким чином, відштовхуючись від однієї із засадних категорій класичного періоду естетичної думки - прекрасного, К. Розенкранц розгортає свої пошуки на теренах потворного, що спрямовує його у площину некласичної естетичної проблематики. При цьому, здійснюючи відповідні концептуальні нашарування, він безпосередньо апелює до певних положень естетики Г.В.Ф. Гегеля, які, вочевидь, зрозумів не так вже і неточно.

Водночас, «понятійне співвідношення» К. Розенкранц застосовує не лише у зв'язку з «офіційною антиномією» потворне-прекрасне, а й спрямовує його й у інші виміри, зокрема - у площину комічного, що, не зважаючи на свій, формально класичний статус, імпліцитно було наявне і у добу некласичної естетики, виявляючи вельми несподівані аспекти у процесі дослідження.

Наразі зазначимо, що питання «взаємозалежності» комічного і потворного доволі часто постає у різних концептуальних контекстах дослідження німецького науковця. При цьому він, вочевидь, сповідує паритетний підхід, апелюючи і до відповідних ідей своїх «теоретичних попередників» і розгортаючи авторську модель зіставлення потворного і комічного. Зокрема, К. Розенкранц звертається до висновку Аристотеля, котрий відзначав, що «у комічному потворне наявне як заперечення прекрасного, хоча, у свою чергу, заперечується і комічним» [5, 63]. Орієнтир давньогрецького мислителя, вочевидь, має для К. Розенкранца принципове значення, однак взаємозв'язок потворного і комічного він досліджує у значно ширшому теоретичному діапазоні.

За великим рахунком, переважна більшість засадних положень філософа, що, власне, і визначають логіку руху його думки, так чи інакше, стосуються означеної проблеми. Зокрема, питання комічного наявне у розмислах К. Розенкранца у контексті всіх трьох наріжних складових, що $€$ ознаками одного з визначальних чинників потворного - форми, точніше ії відсутності. Так, учений фундаментально розглядає взаємозалежність потворного-комічного у зв'язку з аморфним, асиметрією та дисгармонією, неминуче звертаючись до «головного продукту» комічного, каталізатором якого, проте, стає і потворне - сміху. Наразі згадаємо, що у першій половині XX ст. це явище спричинило принаймні два яскравих теоретичних прориви на теренах французької естетики, одним 3 яких, безперечно, стала визначна праця А. Бергсона (1859-1941) «Сміх» (1900).

У цьому зв'язку зазначимо, що у цьому дослідженні, теоретичну значущість якого навряд чи можна переоцінити, питання зв'язку потворного і комічного/смішного, постає майже 3 перших сторінок: «Підсилимо бридке, перетворимо його на потворне і побачимо, як можна перейти від потворного до смішного» [3, 30-31]. Наведений висновок, безперечно, $є$ теоретично суголосним одному з тверджень К. Розенкранца: «... потворне у різноманітності зводиться до відсутності... зв'язку. < ..> Хаотична плутанина і метушня стають можливими тільки у зрізі комічного. Буденна реальність сповнена плутанини, що мала б образити, якби, на щастя, не викликала сміх» $[5,76]$. 
Хоча дослідження французького філософа побачило світ майже через півстоліття після виходу друком праці німецького ученого, А. Бергсон, одначе, жодного разу не посилається на ідеї К. Розенкранца. Це, вочевидь, було зумовлене загальною концептуальною спрямованістю праці «Сміх», що в ній, сказати б, природний зв'язок сміху з певними виявленнями потворного фіксувався, проте не перетворювався на предмет окремого дослідження: «Не викликає заперечень, що певні потворства мають сумну перевагу над іншими викликати сміх. Немає сенсу зупинятися на подробицях. Попросимо лише $<\ldots>$ пригадати різні потворства, потім розділити їх на дві групи, з одного боку, такі, які природа наблизила до смішного, з іншого - які надзвичайно далекі від цього. Гадаємо, що ми без особливих зусиль сформулюємо таку закономірність: смішним може стати будь-яке потворство, відтворене людиною без вад» [3, 31].

Натомість для сучасника i співвітчизника А. Бергсона — Ж. Батая (1897-1962) проблема співвідношення потворного і смішного мала принципове значення, адже безпосередньо вплинула на специфіку важливої складової його трансгресивного досвіду - «сміхову модель» (20-50 pp. $\mathrm{XX}$ ст.), яка $є$ другим очевидним проривом, визначеним нами вище. Проте і Ж. Батай фактично обходить «Естетику потворного» К. Розенкранца, що викликає логічні запитання, принаймні з двох причин.

По-перше, як відомо, свої «філософські університети» французький теоретик і письменник проходив у «гуртку Кожева», де опановував основоположні засади філософії Г.В.Ф. Гегеля. Дослідники доробку Ж. Батая обов'язково фіксують увагу на цьому, без перебільшення, доленосному епізоді у його теоретичному становленні, артикулюючи на одному з основоположних курсів «Лекціях з “Феноменології духу”», що був прочитаний самим О. Кожевим.

Безперечно, його значення для формування теоретичного поля Ж. Батая важко переоцінити, адже звідси, значною мірою, бере свій початок концепція трансгресивного досвіду. Зокрема, український естетик $Є$. Буцикіна артикулює на його особливій увазі до метафоричного гегелівського протиставлення «господар»-«раб» і наголошує: «Проте, обидва поняття були кардинально переосмислені Батаєм. Французький мислитель, на відміну від Г.В.Ф. Гегеля, відмовляє рабу в можливості стати насправді вільною людиною. Якщо за Гегелем людина не народжується вільною, а стає такою впродовж свого історичного розвитку, то за Батаєм статус суверена $є$ наданим від народження» $[4,34]$.

Отже, теоретичні інтереси Ж. Батая до філософії Г.В.Ф. Гегеля взагалі, тим більш - до відповідного аспекту його концептуальних орієнтирів зокрема, майже «прирікали» його виокремити 3 гегелівського оточення постать К. Розенкранца, котрий, так само, як і Ж. Батай, сформувавшись під впливом «Феноменології духу», врешті-решт прийшов до своєї «Естетики потворного». Звідси друга причина, що виявляє очевидний збіг між поглядами Розенкранца і Батая, проте вже не на «загальноосвітньому», а безпосередньо концептуальному рівні.

Як відомо, однією з визначальних ознак «сміхової моделі» Ж. Батая, що відверто дисонувала зі «сміховою моделлю» А. Бергсона, було категоричне заперечення і в літературних творах, і в теоретичних дослідженнях морального імперативу: «Я, так само як і мої друзі, відчуваю, - наголошував Батай, - огиду до навіжених веселощів. Окрім сміху, є смерть $<\ldots>$ втрата свідомості, нестямності, що викликані якоюсь жахливою картиною, перетвореним жахом. У цих $<\ldots>$ ситуаціях я більше не сміюсь: я лише зберігаю почуття сміху (курсив наш - O. O.)» $[1,92]$.

Акцентуація на огиді до «навіжених веселощів», природно, спричинилася до того, що Ж. Батай опинився «по той бік комічного» у площині категорій потворного і низького, котрі, на його думку, породжують вельми специфічний сміх, який потребує окремого аналізу. Проте хоча б на, так би мовити, поверхневому рівні зосередимося на ще одному аспекті «сміхової концепції» Батая, що була екстрапольована ним у площину його літературного твору «Абат С».

Свого героя письменник характеризував шляхом звернення до його «сміхової природи», зокрема, наголошуючи: «Таке відчуття викликала не лише дитяча $-<\ldots>$ обтяжливо комічна $-n p u$ рода "злочинів" (курсив наш - $О$. . .), що їх він брав на себе» $[2,389], \mathrm{i}$, розвиваючи свою думку, відзначав: «Я сміюся. Природно! Це дивовижне людство відповідає вимогам злочиния (курсив наш - $O . O$.), що не може не видаватися низьким» $[2,391]$.

На нашу думку, висновки Ж. Батая можуть бути трансформовані у різні площини - i теоретичні, і художні, спонукаючи дослідників звернутися до ідей маркіза де Сада, Ф. Шіллера, Ч. Ломброзо, В. Гюго, М. Енаффа та інших, котрі, в той чи інший спосіб, порушували проблему злочину, зробивши іiі врешті-решт і предметом міждис- 
циплінарного аналізу, і виявом теоретико-практичного паритету. Безперечно, у цьому контексті «Естетиці потворного» К. Розенкранца належить особливе місце. Адже, розглядаючи принципові для свого дослідження проблеми, що пов'язані 3 розпадом форми/деформацією, які учений вважав, так би мовити, найвищим рівнем потворного, неабияку увагу він, зокрема, приділяв і феномену зла, що його структуру становлять фантомне (містичне), пекельне (сатанинське), але - передусім - беззаконне (злочинне).

Осмислення злочинного К. Розенкранц здійснював вельми фундаментально, виокремлюючи у процесі аналізу і естетичний, і культурно-історичний, і психологічний, і етичний контексти. Однак, чітко визначаючи фундаментом злочинного - потворне, дослідник, звісно, апелював до феномена трагічного, але водночас не обходив і комічне, досліджуючи його у різних ракурсах. Зокрема, він зазначав: «Аморальність злочинної дії не може трансформуватися в комічне, якщо більшою чи меншою мірою не має місце абстрагування від його етичного значення і якщо його еволюція не представлена з інших точок зору» [5, 200-201].

В «Естетиці потворного» розглядаються i «позитивні рішення» цього питання, проте наразі для нас принциповим є сам факт існування концептуального ланцюга потворне - комічне злочинне, що, на нашу думку, дає неабиякі підстави артикулювати більш ніж очевидні перетини у теоретичних орієнтирах К. Розенкранца - А. Бергсона, але, особливо, К. Розенкранца - Ж. Батая. Тож «відсторонення» французьких учених від здобутків свого німецького колеги, безперечно, є дивним, хоча все ж таки його можна пояснити їхнім формальним перебуванням у різних «категоріальних контекстах». Одначе вкрай важко пояснити відверте «ігнорування» теоретичних здобутків «Естетики потворного» тими дослідниками, котрі безпосередньо працювали у цьому ж категоріальному просторі, зокрема - позицію польського науковця М. Валліса (1895-1975).

Як відзначає К. Шевчук, «у 30-х рр. ХХ ст. М. Валліс був єдиним дослідником, який < ..> piшуче окреслював потворне як позитивну естетичну цінність. Естетично потворні предмети здатні, на його думку, викликати естетичне задоволення після початкового почуття образи, тоді як неестетично потворні предмети, огидні такої здатності не мають» [7, 202]. Аналізуючи цю концепцію польського ученого, український науковець здійснює типологію естетично потворних предметів, виокремлюючи експресивно потворні, гротескні та типово потворні, що, вочевидь, слід вважати неабияким внеском М. Валліса у відпрацювання категорії потворного у першій половині XX ст. Проте його концептуальні орієнтири, фактично, $\epsilon$ рефлексією засадних положень К. Розенкранца, які були грунтовно відпрацьовані в «Естетиці потворного» на всіх рівнях процесуального руху: відсутність форми - неточне (невірне) — розпад форми, або Деформації, що до них польський науковець, одначе, не апелює.

Концептуальне наповнення цих чинників, без перебільшення, стало своєрідною «дорожньої картою» для всіх дослідників, котрі надалі, так чи інакше, були дотичні до аналізу категорії потворного, що, відповідним чином, зобов'язувало їх дотримуватися принципу наукової коректності щодо праці К. Розенкранца. Однак процес свідомої чи позасвідомої маргіналізації дослідження німецького ученого продовжувався впродовж усього ХХ ст., що, показово, підтверджує праця «Критика цинічного розуму» (1983) співвітчизника К. Розенкранца - німецького філософа і культуролога П. Слотердайка (н. у 1947 р.).

Своєю гіпертрофованою відвертістю ця, більш ніж неординарна, праця стала справжнім вибухом на європейських інтелектуальних теренах, доволі часто підходячи, а подекуди і переходячи всі можливі провокаційні кордони. Головним стимулом для написання, як це відверто артикулював іï автор, стала ювілейна дата — 200-річчя «Критики чистого розуму» I. Канта, що, зрештою, зумовила наступний висновок П. Слотердайка: «Якщо незадоволеність культурою викликає критику, то, мабуть, наш час, як ніколи, настроює на критику, однак ніколи ще незрозумілий смуток не витісняв $з$ такою силою схильність до критичного імпульсу. Напруження між тим, що хочуть “критикувати", і тим, що має бути “критикованим", посилилося настільки, що наше мислення стало радше стократ більш невдоволеним, ніж точним. Жоден розум не встигає сягнути рівня проблем. Звідси - відмова від критики. <..> Варто дослідити наслідки цього, бо це веде туди, де може йтися про цинізм і “цинічний розум”» $[6,11]$.

Така розлога цитата знадобилася нам задля виокремлення того «камертона», що зрештою визначив концептуальне поле дослідження Слотердайка, яке, без перебільшення, вражає діапазоном своєї проблематики. Цей грандіозний філософсько-культурологічний проект водночас актуалізував вихід його автора і у площину етичної, і психологічної, i політологічної, і естетичної проблематики. Остання, природно, привертає нашу особливу увагу, відкри- 
ваючи неабиякі можливості щодо подальшого самостійного дослідження естетичного/анти-естетичного аспекту «Критики цинічного розуму» ${ }^{1}$.

Наразі ж зазначимо, що естетичний чинник доволі активно наявний у праці П. Слотердайка і на концептуальному рівні, і у своєрідному форматі «мистецького коментування», адже значну частину тексту монографії супроводжують фрагменти творів живопису у зменшеному варіанті. Проте у даному зв'язку артикулюємо один вельми важливий момент - відверте домінування категорії потворного, що у тому чи іншому контексті виникає у праці П. Слодердайка. У цьому плані особливо показовою $є$ iї друга частина — «Цинізм у світовому процесі», де вихід у площину потворного відбувається фактично у кожному розділі, виявляючись у структурі психоматичної проблематики, кардинальних різновидах цинізму, брудній емпірії тощо.

Відтак П. Слотердайк був «концептуально приречений», якщо не послатися, то, принаймні, хоча б назвати, на дослідження «Естетика потворного», однак жодного разу у «Критиці цинічного розуму» ім'я К. Рознекранца не згадується. Це відверте відсторонення виявляється тим більш демонстративним, зважаючи на вельми потужну «персоналізацію» праці П. Слотердайка.

Однак ми переконані, що виявлення і аналіз концептуальних перетинів у цих двох розвідках, вочевидь, відкриє неабиякі теоретичні перспективи щодо осмислення послідовності руху від своєрідного естетичного переживання потворного до відвертого панування цинічного світосприйняття. Як приклад, виокремимо твердження К. Розенкранца, що було висловлене у процесі аналізу незначного (низького, бридкого) у творах XIX ст.: «Чим більш нарочита сила жорстокості, чим більш рафінованою $є$ насолода розпусною жорстокістю, тим більш вони грубі, і тим більш потворні з естетичної точки зору...» $[5,162]$. Його безпосередній розвиток відповідно до вищевизначеної нами послідовності, знаходимо у П. Слотердайка: «Ось чому його (буржуа - O.O.) ідеали постійно підточують реалістичні здогади - i ця суперечність $\epsilon$ такою, що робить буржуазного чоловіка особливо чутливим щодо сексуально-цинічного жарту, брудного реалізму замкової шпарини та порнографії. Буржуа залежить від «високого піднесення своїх цінностей», однак - не без розуміння того,

\footnotetext{
1 Зокрема, значний інтерес викликає підрозділ «Дадаїська хаотологія», що, вочевидь, виявляє принципово нові виміри для дослідження передвісника сюрреалістичного напряму - дадаїзму.
}

що відбувається “внизу в дійсності”. Звідси — цинічна посмішка...» $[6,264]$.

О. Вайльду, як відомо, належить твердження, що кожна людина має право на помилку. Перефразувавши його, завважимо, що кожний дослідник, у разі потреби, має право на «теоретичну реабілітацію» доробку певних учених, наразі - праці Карла Розенкранца «Естетика потворного», завдяки якій відновлюється послідовність історичного і концептуального поступу у вивченні цього феномена в умовах XX ст.

\section{Джерела та література}

1. Батай Жорж. О Ницше / Жорж Батай. - М. : Культурная революция, 2010. - $336 \mathrm{c}$.

2. Батай Ж. Ненависть к поезии: Порнолатрическая проза [: авторський сб. : «История глаза», «Небесная синь», «Юлия», «Невозможное», «Аббат C», «Divinus Deus»] / Жорж Батай. - М. : Ладомир, 1999. - 614 с.

3. Бергсон А. Сміх. Нарис про значення комічного / А. Бергсон. - К. : Національний університет «Києво-Могілянська Академія», 1994. - 164 с.

4. Буцикіна Є. О. Концепція трансгресивного досвіду Жоржа Батая: естетичний аналіз. - Дисертація (рукопис) на здобуття наук. ступеня кандидата філософських наук. K., 2015. - $181 \mathrm{c}$.

5. Шкепу М. Эстетика безобразного Карла Розенкранца / Ин-т проблем соврем. искусства Нац. акад. Искусств / Мария Шкепу. - К. : Феникс, 2010. — 448 с.

6. Слотердайк П. Критика цинічного розуму ; пер. $з$ нім. А. Богачова / Петер Слотердайк. - К. : ВК ТОВ «Тандем», 2002 (серія «Сучасна гуманітарна бібліотека»). — 544 с.

7. Шевчук К. С. Аксіологічний вимір естетичного переживання в польській естетиці першої половини XX ст. Дисертація/ рукопис, 2017. - 402 с.

8. Шестаков В. Очерки по истории эстетики. От Сократа до Гегеля / В. П. Шестаков. — М. : Мысль, 1979. — 372 с.

\section{References}

1. Batay, Zhorzh. O Nitsshe / Zhorzh Batay. - M. : Kulturnaya revolyutsiya, 2010. - 336 s.

2. Batay, Zh. Nenavist $\mathrm{k}$ poezii: Pornolatricheskaya proza [: avtorskiy sb. : «Istoriya glaza», «Nebesnaya sin», «Yuliya», «Nevozmozhnoe», «Abbat S», «Divinus Deus»] / Zhorzh Batay. - M. : Ladomir, 1999. — $614 \mathrm{~s}$.

3. Berhson, A. Smikh. Narys pro znachennia komichnoho / A. Berhson. - K. : Natsionalnyi universytet «KyievoMohilianska Akademiia», 1994. — $164 \mathrm{~s}$.

4. Butsykina, Ye. O. Kontseptsiia transhresyvnoho dosvidu Zhorzha Bataia: estetychnyi analiz. - Dysertatsiia (rukopys) na zdobuttia nauk. stupenia kandydata filosofskykh nauk. K., 2015. - $181 \mathrm{~s}$.

5. Shkepu, M. Estetika bezobraznogo Karla Rozenkrantsa / In-t problem sovrem. iskusstva Nats. akad. Iskusstv / Mariya Shkepu. - K. : Feniks, 2010. - 448 s.

6. Sloterdaik, P. Krytyka tsynichnoho rozumu ; per. z nim. A. Bohachova / Peter Sloterdaik. - K. : VK TOV «Tandem», 2002 (seriia «Suchasna humanitarna biblioteka»). $-544 \mathrm{~s}$.

7. Shevchuk, K. S. Aksiolohichnyi vymir estetychnoho perezhyvannia $\mathrm{V}$ polskii estetytsi pershoi polovyny KhKh st. - Dysertatsiia/ rukopys, 2017. - $402 \mathrm{~s}$.

8. Shestakov, V. Ocherki po istorii estetiki. Ot Sokrata do Gegelya / V. P. Shestakov. — M. : Myisl, 1979. — 372 s. 